POWER BEAMING PROVIDING A SPACE POWER

INFRASTRUCTURE

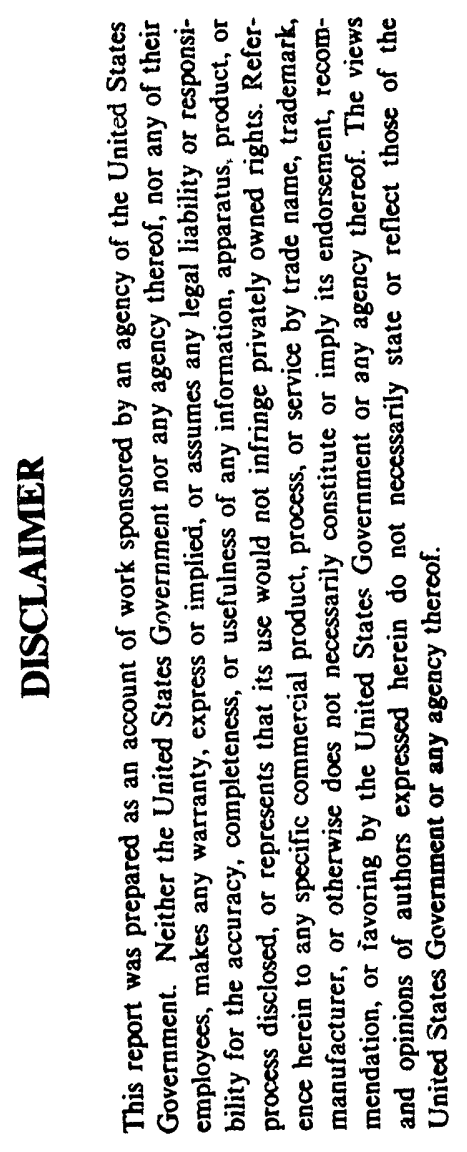
J. A. Bamberger
E. P. Coomes

August 1992

Presented at the 27th Intersociety Energy Conversion Engineering Conference August 3-7, 1992

San Diego, California

Prepared for

the U.S. Department of Energy

under Contract DE-ACO6-76RLO 1830

Pacific Northwest Laboratory

Richland, Washington

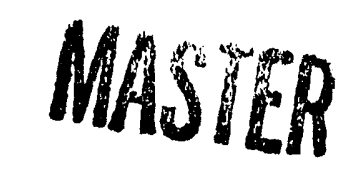

BISTRIBUTION OF THIS UOCUMENT IS UMLIMITER 


\title{
POWER BEAMING \\ PROVIDING A SPACE POWER INFRASTRUCTURE
}

\author{
Judith Ann BAMBERGER and Edmund P. COOMES \\ Pacific Northwest Laboratory (a) \\ P.O. Box 999 M/S K7-15 \\ Richland, Washington 99352
}

\section{ABSTRACT}

This study, based on two levels of technology, applies the power beaming concept to four planned satellite constellations. The analysis shows that with currently available technology, power beaming can provide mass savings to constellations in orbits ranging from low earth orbit to geosynchronous orbit. Two constellations, space surveillance and tracking system and space based radar, can be supported with current technology. The other two constellations, space-based laser array and boost surveillance and tracking system, will require power and transmission system improvements before their breakeven specific mass is achieved. A doubling of SP-100 conversion efficiency from 10 to $20 \%$ would meet or exceed breakeven for these constellations.

\section{INTRODUCTION}

The power system is a major component of a space system's size, mass, technical complexity, and hence, cost. In current design, the energy source is an integral part of the mission satellite. Potentially significant benefits could be realized by replacing the satellite's power system with a receiver and transmitting the power via an energy beam from a distant power satellite. ${ }^{1}$ This concept parallels the terrestrial central generating station with its transmission grid. In this paper, the system components required for power beaming implementation are outlined and applied to several proposed satellite constellations to demonstrate the feasibility of implementing power beaming.

\section{BEAM-POWER SYSTEM}

In a beam-power system, as shown in Figure 1, the power system and user are separated by $\geq 10^{5} \mathrm{~km}$. The central power system is coupled with a transmitter to transmit power to each remote user; each remote user is equipped with a receiver to receive power from the central power system. Selecting the transmitter and receiver involves optimizing four parameters: 1) the transmission distance, 2) the transmission frequency, 3) the power level transmitted, and 4) the thermal rejection capacity of the components. The power transmission distance is the key parameter for determining the operating frequency because the ratio of power received to power transmitted is a function of the transmitter and receiver aperture area, the transmission distance, and the operating frequency.

Radio frequencies (a microwave system) and optical frequencies (a laser system) are viable options for wireless energy transmission in space. Microwave technology is available today at $2.45 \mathrm{GHz}$. 2,3 Solidstate laser technology (a 0.833 micron laser transmitter and photovoltaic receiver) is being developed and would be available early in the next century. ${ }^{4}$ Both technologies are viable in the projected time frames being considered for transition to power beaming. Therefore, system selection becomes a tradeoff among the specific mission or energy application, the transmission distances, and the end-use energy needs.

(a) Operated for the U.S. Department of Energy by Battelle Memorial Institute under Contract DEAC06-76RLO 1830. 


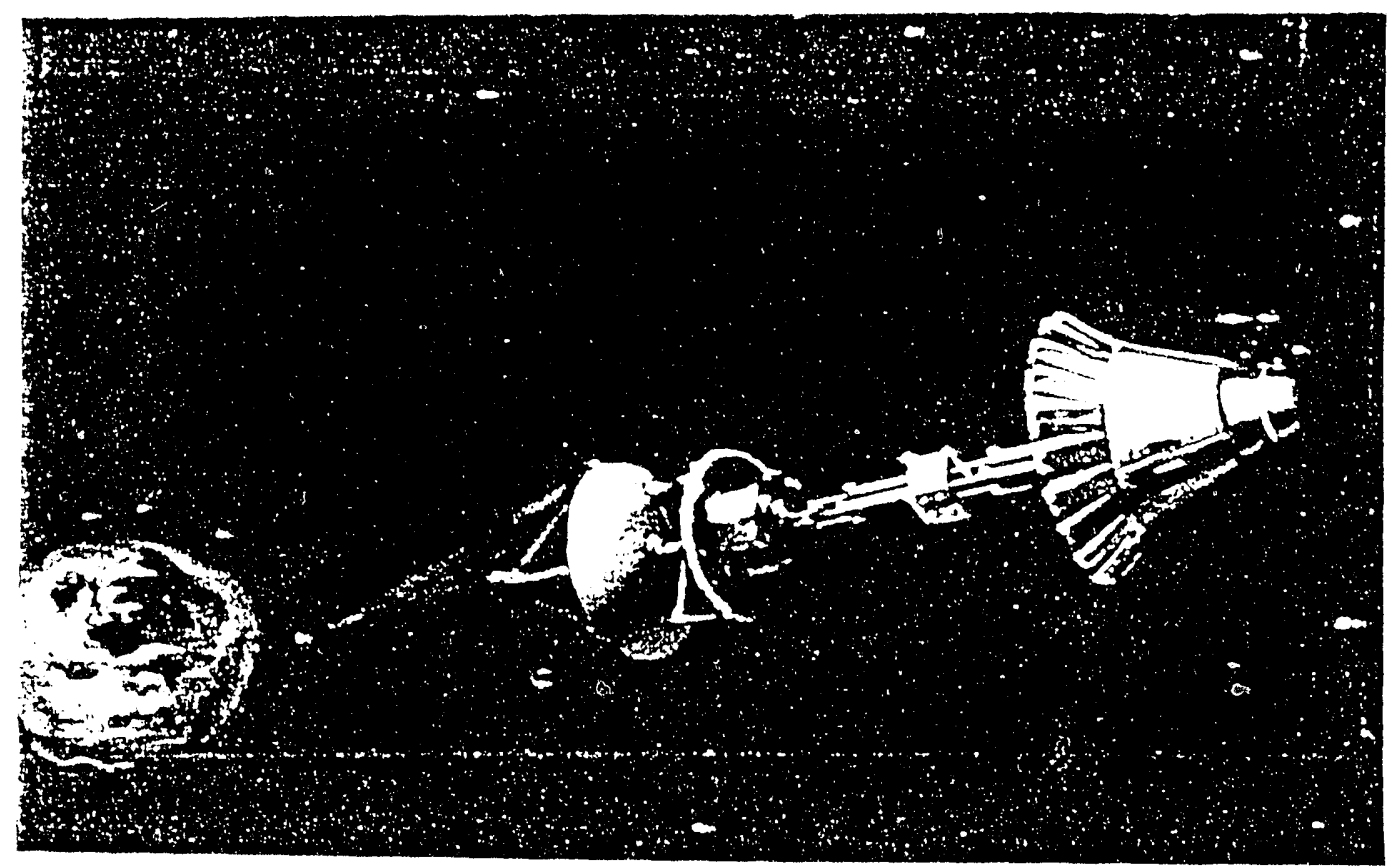

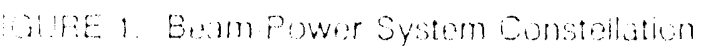

matement power tomaning an appropriate

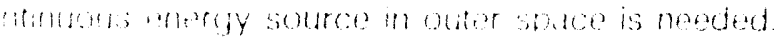

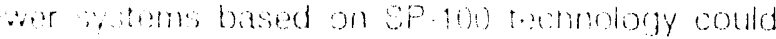

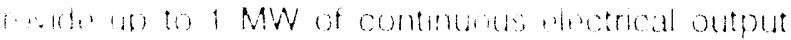

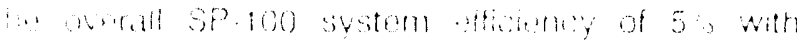

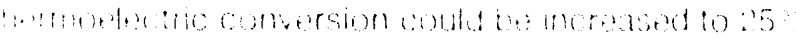

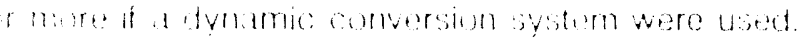

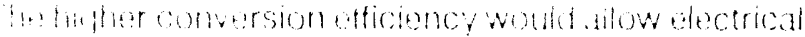

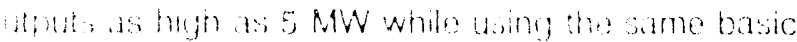

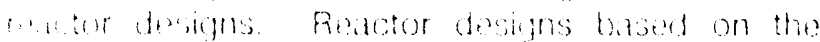

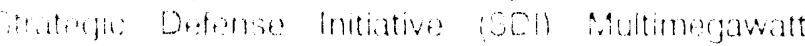

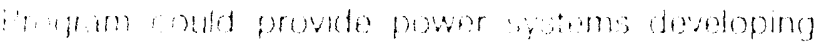

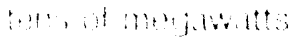

\section{PLATFORM ASSESSMENT WITH POWER BEAMING}

In thes study two types of orbitim shace plitforms.

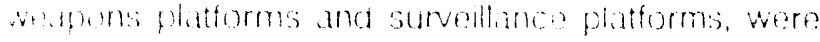
matyent as compare the benefits of power beaming wht thet corrent architecture. An analysis was cumblated to replace the on biand power system: wht power receptors that track power sallollites in a

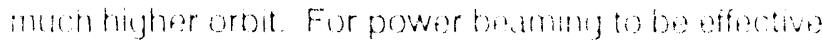

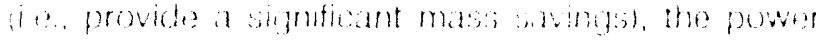
syotem to be peplaced must be segniticanty heaver thin the power system usted to drue the bom power sitrillite?

Four satellte constellations were matyent 1)

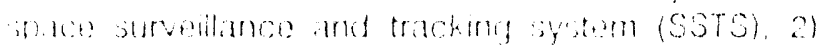

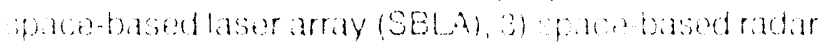

(SBP) and t) boost survollanco and trathing sotum

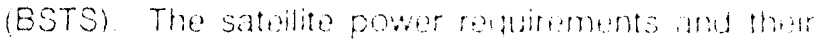
masses are summarlod in Tiam 1

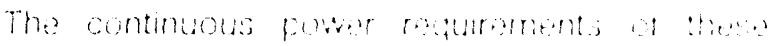

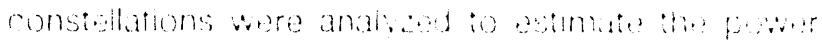
system mass. The base ine berm-power phathm

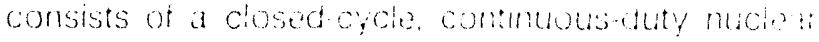
power source powerng a sold sine haser. The pasere

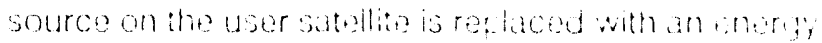
recoptor using conventional photowtate echnohog

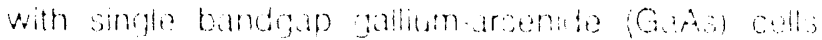

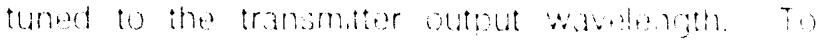

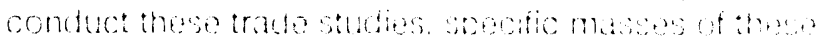

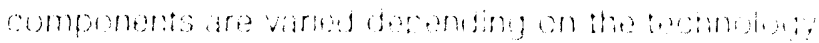

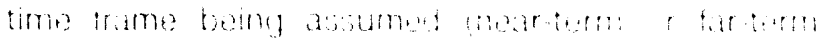

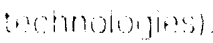

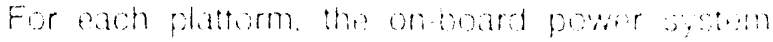

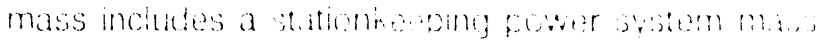

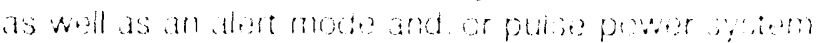

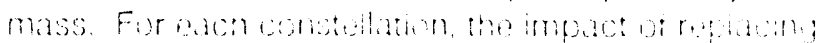

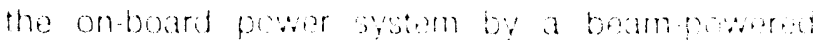

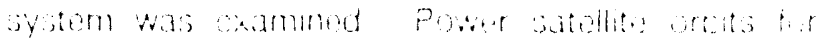

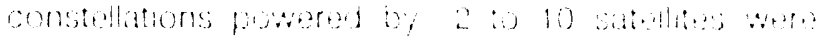

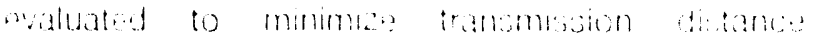

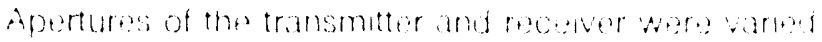

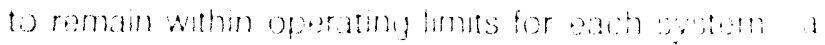

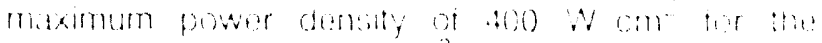

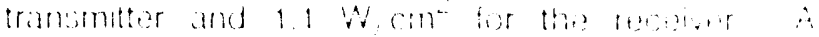

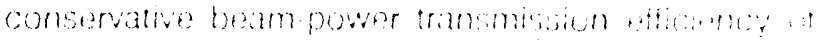

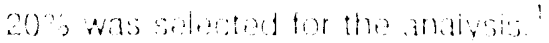


TABLE 1. Constellation Details

\begin{tabular}{|c|c|c|c|c|}
\hline Constellation & SSTS & SBLA & SBR & BSTS \\
\hline Number of satellites & 20 & 36 & 20 & 10 \\
\hline $\begin{array}{l}\text { Power per satellite. } \mathrm{kW} \\
\text { Stationkeeping } \\
\text { Burst mode } \\
\text { Combined }\end{array}$ & $\begin{array}{r}8 \text { to } 14 \\
5 \text { to } 15 \\
13 \text { to } 29\end{array}$ & $\begin{array}{r}60 \text { to } 100 \\
60 \text { to } 100 \\
120 \text { to } 200\end{array}$ & $\begin{array}{l}300 \text { to } 600 \\
500 \text { to } 500 \\
800 \text { to } 1100\end{array}$ & $\begin{array}{l}10 \\
10\end{array}$ \\
\hline Engagement zone, degrees & 90 & 90 & 90 & -- \\
\hline Power transmission efficiency, $\%$ & 20 & 20 & 20 & 20 \\
\hline Power system mass/satellite, $\mathrm{kg}$ & 800 to 1100 & 2500 to 3300 & 30000 & 940 to 1600 \\
\hline
\end{tabular}

For each constellation two technology projections were considered: a near-term projection of technology status in approximately 5 to 10 years and a far-term projection of technology status in 10 to 15 years. These projections were directly reflected in the specific masses of the beam-power system components. An SP-100 reactor with a specific mass of $33 \mathrm{~kg} / \mathrm{kW}$ represented near-term technology. An advanced SP-100 reactor with a specific mass of 2 $\mathrm{kg} / \mathrm{kW}$ represented far-term technology. For the transmitter, a near-term specific mass of $10 \mathrm{~kg} / \mathrm{kW}$ was selected while the far-term specific mass decreased to $1 \mathrm{~kg} / \mathrm{kW}$. For the receiver, the specific mass was held constant at $3 \mathrm{~kg} / \mathrm{kW}$. Details of the analyses are presented for the space surveillance and tracking system constellation. Results for all constellations are listed in Tables 2 and 3.

Space Surveillance and Tracking System Analysis The Space Surveillance Tracking System, ${ }_{1}{ }^{5}$ is a constellation of 20 satellites located in high-Earth orbit. Transmitter and receiver apertures were varied to remain within the operating limits for the systems. These constraints set the receiver diameter at $\geq 1.8 \mathrm{~m}$.

Each satellite requires 8 to $14 \mathrm{~kW}$ of continuous power; burst power requirements range from 5 to 15 $\mathrm{kW}$, with the maximum required power of $29 \mathrm{~kW}$ (Table 1). A conservative beam-power transmission efficiency of $20 \%$ was chosen. The entire constellation would require a beam-power satellite system with a minimum power capacity of at least 925 $\mathrm{kW}$. This assumes that stationkeeping power is available during the entire orbit and burst power is available for one-quarter of the orbit.
The mass trade-off based on near-term and farterm technology maturity is summarized in Table 2. The beamed-power option provides a mass savings for all of the assumptions except the minimum mass assumptions for greater than three beam-power satellites. The far-term assumptions show a significant mass savings in all cases.

Breakeven values for the specific masses of the power system were calculated and are summarized in Table 3. For the near-term transmitter specific mass of $10 \mathrm{~kg} / \mathrm{kW}$ and a receiver specific mass of $3 \mathrm{~kg} / \mathrm{kW}$, the breakeven power system mass ranged from 26 to $52 \mathrm{~kg} / \mathrm{kW}$. The second analysis using the far-term transmitter specific mass of $1 \mathrm{~kg} / \mathrm{kW}$ and a receiver specific mass of $3 \mathrm{~kg} / \mathrm{kW}$, showed that the breakeven power system mass ranged from 39 to $61 \mathrm{~kg} / \mathrm{kW}$.

With the current approach, SSTS will require the launch of approximately $22,000 \mathrm{~kg}$ of power system mass to provide enough power for the entire satellite constellation. By utilizing power beaming, the power system mass required is reduced to 7,000 or 13,000 $\mathrm{kg}$, depending on the specific mass assumptions for the power system.

Space-Based Laser Array - This constellation includes 36 satellites located in mid-Earth orbit. Based on power requirements, receiver diameter is $\geq 4.8 \mathrm{~m}$. Based on near-term technology status, the beam power option does not provide mass savings; however, significant mass savings is obtained when far-term technology projections are considered (Table 2). Analyses to determine the power system-specific mass required to breakeven (Table 3 ) show that a 25 to $30 \%$ improvement in the existing SP-100 system specific mass is needed to reach this point. 
TABLE 2. Power System Mass Analysis for State-of-the-Art and Advanced Concept SP-100 Reactor for a Minimum Receiver Diameter

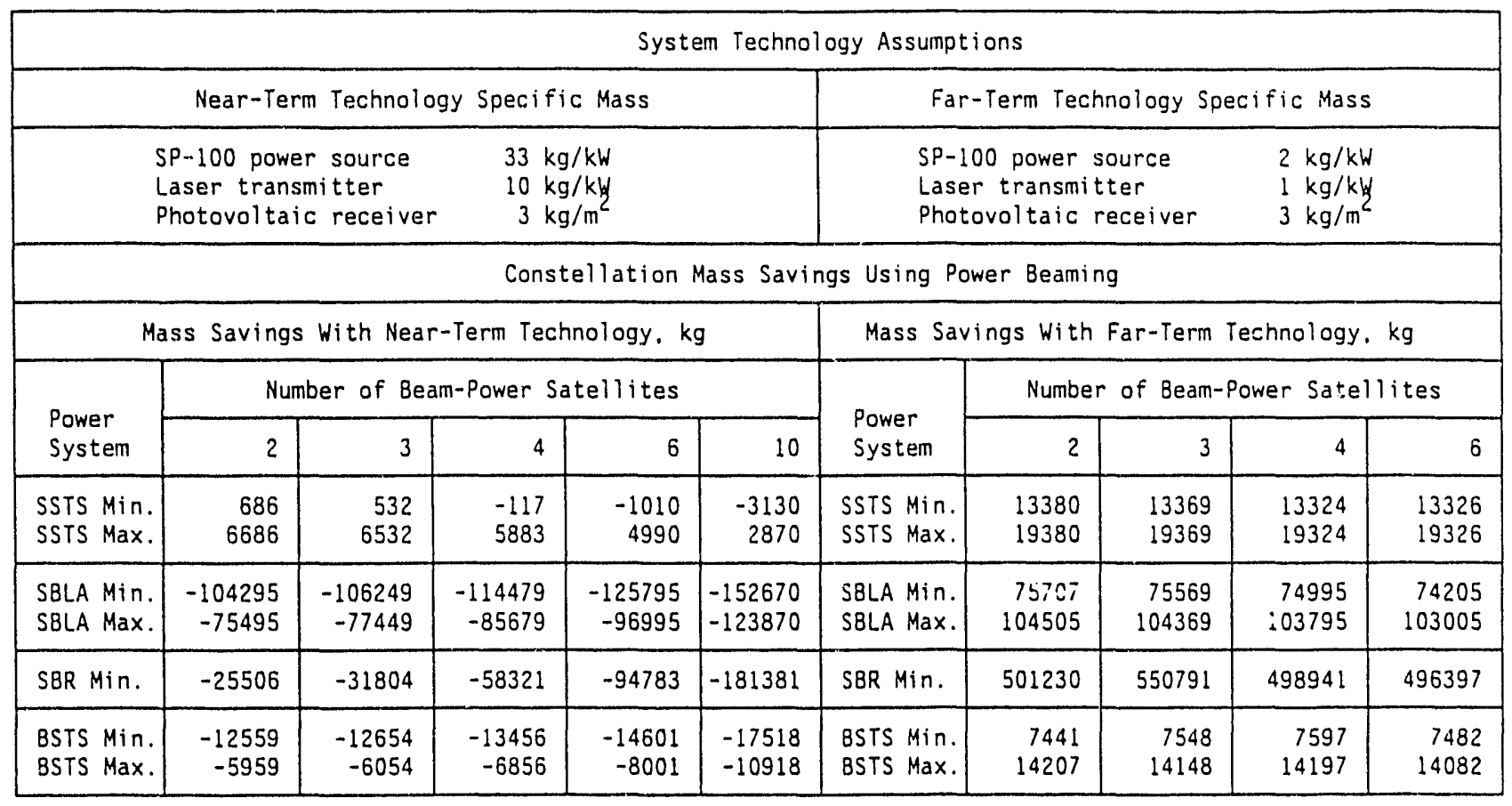

BSTS based on 15-m diameter transmitter.

TABLE 3. Power System Breakeven Point for State-of-the-Art and Advanced Concept Transmitter at a Minimum Receiver Diameter

\begin{tabular}{|c|c|c|c|c|c|c|c|c|c|c|}
\hline & \multicolumn{10}{|c|}{ System Technology Assumptions } \\
\hline \multicolumn{6}{|c|}{ Near-Term Technology Specific Mass } & \multicolumn{5}{|c|}{ Far-Term Technology Specific Mass } \\
\hline & \multicolumn{2}{|c|}{$\begin{array}{l}\text { SP-100 power source } \\
\text { Laser transmitter } \\
\text { Photovoltaic receive }\end{array}$} & \multicolumn{3}{|c|}{$\begin{array}{r}T B D \mathrm{~kg} / \mathrm{kW} \\
10 \mathrm{~kg} / \mathrm{kH} \\
3 \mathrm{~kg} / \mathrm{m}^{2}\end{array}$} & \multicolumn{3}{|c|}{$\begin{array}{l}\text { SP-100 power source } \\
\text { Laser transmitter } \\
\text { Photovoltaic receiver }\end{array}$} & \multicolumn{2}{|c|}{$\begin{array}{r}T B D \mathrm{~kg} / \mathrm{kW} \\
1 \mathrm{~kg} / \mathrm{kW} \\
3 \mathrm{~kg} / \mathrm{m}^{2}\end{array}$} \\
\hline \multicolumn{11}{|c|}{ Beam-Power Satellite Power Source Specific Mass To Breakeven } \\
\hline \multicolumn{6}{|c|}{ Breakeven Point With Near-Term Technology. $\mathrm{kg} / \mathrm{kW}$} & \multicolumn{5}{|c|}{ Breakeven Point With Far-Term Technology. kg/kW } \\
\hline \multirow{2}{*}{$\begin{array}{l}\text { Power } \\
\text { System }\end{array}$} & \multicolumn{5}{|c|}{ Number of Beam-Power Satellites } & \multirow{2}{*}{$\begin{array}{l}\text { Power } \\
\text { System }\end{array}$} & \multicolumn{4}{|c|}{ Number of Beam-Power Satellites } \\
\hline & 2 & 3 & 4 & 6 & 10 & & 2 & 3 & 4 & 6 \\
\hline $\begin{array}{l}\text { SSTS Max. } \\
\text { SSTS Min. }\end{array}$ & $\begin{array}{l}52 \\
35\end{array}$ & $\begin{array}{l}51 \\
34\end{array}$ & $\begin{array}{l}49 \\
33\end{array}$ & $\begin{array}{l}46 \\
30\end{array}$ & $\begin{array}{l}40 \\
26\end{array}$ & $\begin{array}{l}\text { SSTS Max. } \\
\text { SSTS Min. }\end{array}$ & $\begin{array}{l}61 \\
44\end{array}$ & $\begin{array}{l}60 \\
43\end{array}$ & $\begin{array}{l}58 \\
42\end{array}$ & $\begin{array}{l}55 \\
39\end{array}$ \\
\hline $\begin{array}{l}\text { SBLA Max. } \\
\text { SBLA Min. }\end{array}$ & $\begin{array}{l}16 \\
10\end{array}$ & $\begin{array}{l}16 \\
10\end{array}$ & $\begin{array}{r}15 \\
9\end{array}$ & $\begin{array}{r}14 \\
8\end{array}$ & $\begin{array}{r}11 \\
6\end{array}$ & $\begin{array}{l}\text { SBLA Max. } \\
\text { SBLA Min. }\end{array}$ & $\begin{array}{l}25 \\
19\end{array}$ & $\begin{array}{l}25 \\
19\end{array}$ & $\begin{array}{l}24 \\
18\end{array}$ & $\begin{array}{l}23 \\
17\end{array}$ \\
\hline SBR Min. & 31 & 31 & 29 & 27 & 23 & SBR Min. & 40 & 40 & 38 & 36 \\
\hline $\begin{array}{l}\text { BSTS Max. } \\
\text { BSTS Min. }\end{array}$ & $\begin{array}{r}22 \\
9\end{array}$ & $\begin{array}{r}22 \\
9\end{array}$ & $\begin{array}{r}20 \\
8\end{array}$ & $\begin{array}{r}19 \\
7\end{array}$ & $\begin{array}{r}16 \\
5\end{array}$ & $\begin{array}{l}\text { BSTS Max. } \\
\text { BSTS Min. }\end{array}$ & $\begin{array}{l}31 \\
18\end{array}$ & $\begin{array}{l}31 \\
18\end{array}$ & $\begin{array}{l}28 \\
17\end{array}$ & $\begin{array}{l}28 \\
16\end{array}$ \\
\hline
\end{tabular}

BSTS Max. based on 20-In diameter transmitter. BSTS Min. based on 10-m diameter transmitter.

TBO: to be determined in the analysis. 
TABLE 4. Comparison of Breakeven Specific Masses for Platform Applications

\begin{tabular}{|l|c|c|c|}
\hline \multirow{2}{*}{ Satellite } & Minimum Receiver & \multicolumn{2}{|c|}{ Beam Power Satellite Specific Mass. kg/kW } \\
\cline { 3 - 4 } & Diameter, m & $\begin{array}{c}\text { State-of-the-Art } \\
\text { Transmitter }\end{array}$ & $\begin{array}{c}\text { Advanced Concept } \\
\text { Transmitter }\end{array}$ \\
\hline SSTS & 1.83 & $26-52(\mathrm{a})$ & $35-61(\mathrm{~b})$ \\
\hline SBLA & 4.81 & $6-16$ & $17-25(\mathrm{~b})$ \\
\hline SBR & 11.28 & $23-31(\mathrm{a})$ & $36-40(\mathrm{~b})$ \\
\hline BSTS & varies & $5-22$ & $16-31$ \\
\hline
\end{tabular}

Space-Based Radar - This constellation includes 20 satellites located in high-Earth orbit. Based on power requirements, receiver diameter is limited to $\geq 11.3 \mathrm{~m}$. Mass analyses (Tables 2 and 3 ) show that mass savings are obtained based on far-term technology status. Only a $6 \%$ specific mass improvement in the existing SP-100 configuration is necessary to breakeven.

Boost Surveillance and Tracking System - This constellation includes 10 satellites located in geosynchronous orbit. Mass analyses (Tables 2 and 3) show that mass savings are obtained based on farterm technology status. Only a modest improvement in the existing SP-100 system-specific mass is needed to reach the breakeven point. A doubling of the SP. 100 conversion efficiency from $5 \%$ to $10 \%$ would meet or exceed breakeven. Conversion efficiency could be improved by utilizing dynamic conversion (either a Brayton engine or a free piston Sterling engine). Further improvement could be achieved by using an advanced lightweight radiator, such as the fabric heat pipe radiator. 6.7

\section{CONCLUSIONS}

This study, based on two levels of technology maturity, has shown that witi currently available technology, power beaming can provide mass savings to a variety of constellations in orbits ranging from low-Earth orbit to geosynchronous orbit. A summary of the power system breakeven specific masses for $i$. ? platforms is listed in Table 4. SSTS and SBR can be supported with current technology, while SBLA and BSTS will require power and transmission system improvements before their breakeven specific mass is achieved.
A doubling of SP-100 conversion efficiency from 10 to $20 \%$ would meet or exceed breakeven for both constellations.

Power beaming can significantly improve future space missions. Beam-power transmission is technically feasible. The systems, transmitters, receivers, and power sources are expected to be available in a time frame compatible with proposed deployment schedules. Power beaming is most attractive and can provide significant benefit for stationkeeping and alert mode power. With near-term technologies, power beaming can provide the stationkeeping and alert mode power for only one-half of the on-orbit mass of the currently proposed power system.

\section{ACKNOWLEDGMENTS}

This work was performed by the Pacific Northwest Laboratory and supported by the U.S. Department of Energy under Contract Number DE. AC06-76RLO 1830. This work is an extension of a study initially funded by the Strategic Defense Initiative Office (SDIO) under the direction of David Buden and Dick Verga of the Office of Survivability, Lethality, and Key Technologies. 


\section{REFERENCES}

1. Coomes, E.P., J.A. Bamberger and L.A. McCauley. (1989). An Assessment of the Impact of Free Space Electromagnetic Energy Transmission of Strategic Defense Initiative Systems and Architectures. PNL-6932, Pacific Northwest Laboratory, Richland, Washington.

2. U.S. Department of Energy/National Aeronautics and Space Administration. (1978). Satellite Power System: Concept Development and Evaluation Program. DOE/ER-0023, U.S. Department of Energy, Washington, DC.

3. U.S. Department of Energy. (1980). The Final Proceedings of the Sular Power Satellite Program Review. DOE/NASA Conference Publication 800491, U.S. Department of Energy, Washington, DC.

4. U.S. Department of Energy/National Aeronautics and Space Administration. (1978). Potential of Laser for SPS Power Transmission. HCP/R-4024-07, U.S. Department of Energy, Washington, DC.

5. General Electric. (1987). Space Power Architecture Study (SPAS) Interim Report: Task $J$ Conceptual Designs of Space Power Subsystem Operation(U). General Electric, Spacecraft Operations, Valley Forge, AstroSpace Division, Philadelphia, Pennsylvania.

6. Antoniak, Z. I., W. J. Krotiuk, B. J. Webb, J. T. Prater, and J. M. Bates. (1988). Fabric Space Radiators. PNL-6458, Pacific Northwest Laboratory, Richland, Washington.

7. Antoniak, Z. I., J. M. Bates, and B. J. Webb. (1990). "Construction and Testing of Advanced Ceramic Fabric Radiator Components to 1000 K." In Seventh Symposium on Space Nuclear Power Systems, pp. 867-869, Institute for Space Nuclear Power Studies, Albuquerque, New Mexico. 


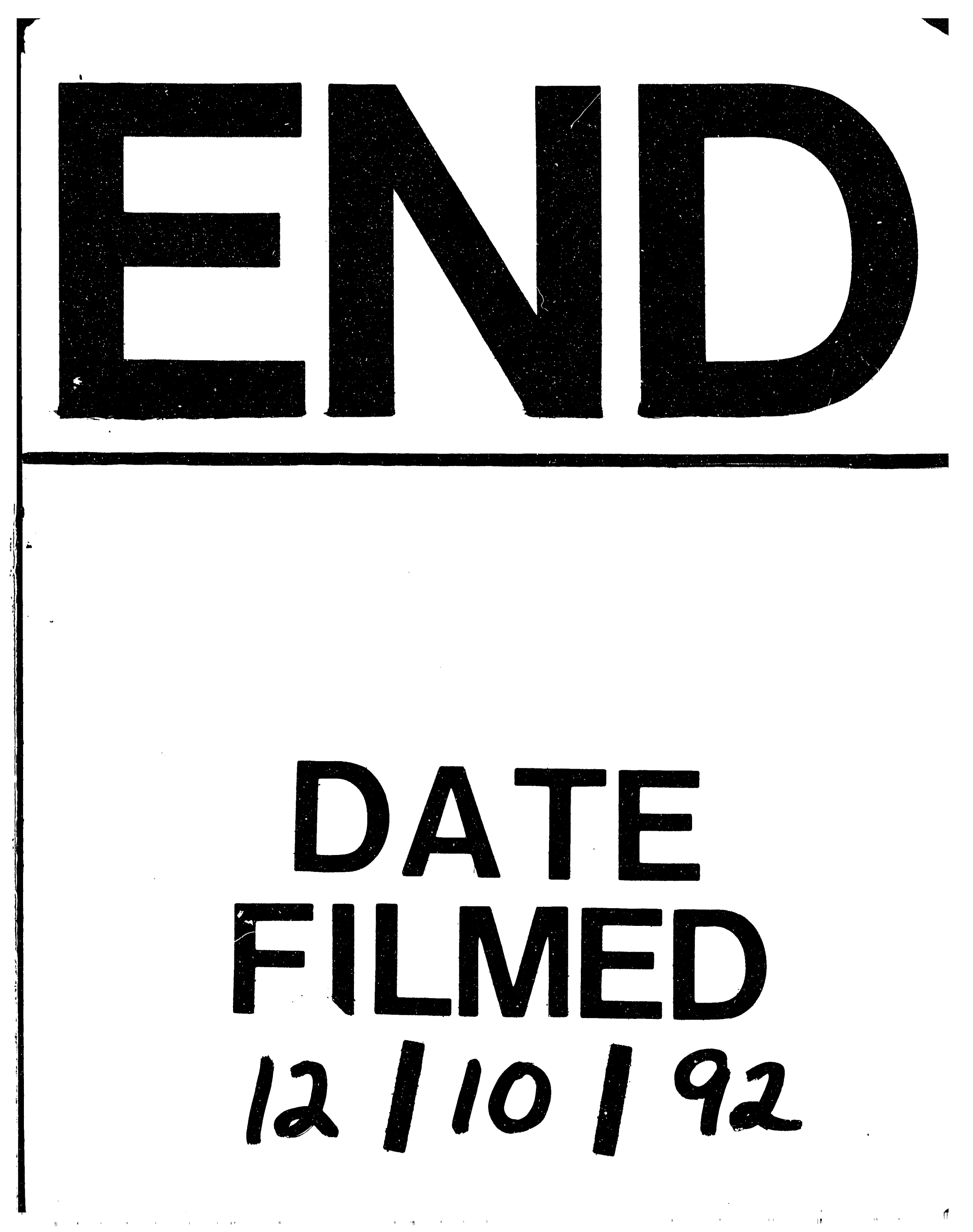


